\title{
A Unique Receptor-independent Mechanism by which Insulinlike Growth Factor I Regulates the Availability of Insulinlike Growth Factor Binding Proteins in Normal and Transformed Human Fibroblasts
}

Cheryl A. Conover

Endocrine Research Unit, Mayo Clinic, Rochester, Minnesota 55905

\begin{abstract}
Insulin-like growth factor I and II (IGF-I and IGF-II) associate with specific IGF binding proteins (IGFBPs) present in plasma and extracellular fluids that can modulate the anabolic effects of these peptides. IGF-I has been shown to increase IGFBP concentrations in vivo and in vitro, but the mechanism and significance of this action are unknown. We examined these issues using normal and simian virus 40-transformed adult human fibroblasts (SV40-HF) in culture. Treatment with IGF-I markedly stimulated the appearance of IGFBP-3 (42/38 $\mathrm{kD}$ doublet), a $36 \mathrm{kD}$ IGFBP, and 28-32 kD IGFBPs in the medium of these cells, as assessed by Western ligand blotting; IGF-I decreased levels of $24 \mathrm{kD}$ IGFBP in normal HF cultures. The IGF-I-induced change in IGFBP levels was not a type I IGF receptor-mediated effect on IGFBP synthesis because $(a)$ high concentrations of insulin did not mimic IGF-I's effect; (b) IGFII and IGF-I analogues having reduced affinity for the IGF-I receptor were equipotent with IGF-I in increasing medium IGFBPs; (c) [QAYL]IGF-I, an IGF-I analogue having normal receptor affinity and decreased affinity for IGFBPs, had no effect; and (d) $\alpha$ IR-3, a monoclonal antibody specific for the type I IGF receptor, did not block IGF-I-stimulated increases in IGFBPs. In physiological studies, preincubation with $1 \mathrm{nM}$ IGF-I had no effect on type I IGF receptor binding in normal HF and SV40-HF. In contrast, preincubation of cells with an equivalent concentration of [QAYL]IGF-I downregulated the receptors $\mathbf{4 0 - 5 0 \%}$. Changes in cell surface receptor number were reflected in cell responsiveness to IGF-I-stimulated $\left[{ }^{3} \mathbf{H}\right]$ thymidine incorporation and $\left[^{3} \mathrm{H}\right]$ aminoisobutyric acid uptake. In conclusion, IGF-I regulates the availability of specific IGFBPs in cultured human fibroblasts by a novel receptor-independent mechanism. Rapid changes in levels of soluble IGFBPs as a direct response to extracellular IGF-I, in turn, modulate IGF-I peptide and receptor interaction, and may constitute an important level of control in IGF cellular physiology. (J. Clin. Invest. 1991. 88:1354-1361.) Key words: IGF-I • IGFBP-3 • IGF-I analogues • type I IGF receptor • downregulation - thymidine incorporation
\end{abstract}

This work was presented, in part, at the 12-16 January 1991 International Symposium on Insulin-Like Growth Factors/Somatomedins, San Francisco, CA.

Address reprint requests to Dr. Cheryl Conover, Endocrine Research Unit, Mayo Clinic and Mayo Foundation, Rochester, MN 55905.

Received for publication 11 February 1991 and in revised form 23 April 1991.

J. Clin. Invest.

(C) The American Society for Clinical Investigation, Inc. 0021-9738/91/10/1354/08 \$2.00

Volume 88, October 1991, 1354-1361

\section{Introduction}

The insulin-like growth factors I and II (IGF-I, IGF-II) are growth hormone $(\mathrm{GH})^{1}$-dependent peptides ancestrally related to insulin that have potent growth-promoting and insulin-like effects in vivo and in vitro (1). Unlike insulin, these peptides associate with distinct proteins present in serum and other biological fluids, as well as in medium conditioned by cultured cells (2). Multiple insulin-like growth factor binding proteins (IGFBPs) have been identified, and full amino acid sequence has been determined for four of these proteins (3-9).

At present, the factors regulating IGFBP synthesis and secretion are not completely understood. IGFBP-3 has been referred to as the GH-dependent IGFBP; however, recent evidence suggest that in vivo IGF-I mediates GH-associated increases in IGFBP-3 levels $(10,11)$. Subcutaneous infusion of IGF-I in healthy adults also raises serum levels of IGFBP-2 (12). Moreover, IGF-I stimulates the release of various IGFBPs, including IGFBP-3, in cultured cells (13-18). Because IGFBPs can alter IGF-I receptor binding (19-21) and are able to potentiate or attenuate the metabolic and mitogenic actions of IGF-I (19, 22, 23), IGF-I-induced increases in IGFBPs may play an important role in controlling local cell responsiveness to this growth factor. The mechanism(s) by which IGF-I promotes increased availability of its own IGFBPs and the potential significance of this action have not been determined.

In this study, we investigated the mechanism by which IGF-I regulates IGFBPs in cultures of SV40 (simian virus 40)transformed and normal adult human fibroblasts. These cells synthesize and secrete several IGFBPs, one of which is physiologically and immunologically related to human IGFBP-3 (24, 25). We present evidence that IGF-I regulation of IGFBP availability in human fibroblasts is a novel receptor-independent process that is an important physiological component of cell growth homeorrhesis.

\section{Methods}

Materials. Recombinant DNA-derived Thr ${ }^{59}$-IGF-I was purchased from Amgen Biologicals (Thousand Oaks, CA), and IGF-II was from Bachem, Inc. (Torrance, CA). IGF-I analogues obtained by site-directed mutagenesis, [ser $\left.{ }^{24}\right]$ IGF-I, [1-27,Gly, $\left.38-70\right]$ IGF-I, and [Gln ${ }^{3}$, $\mathrm{Ala}^{4}, \mathrm{Tyr}^{15}$, Leu $\left.^{16}\right]$ IGF-I ([QAYL]IGF-I), were generous gifts of Dr. M. Cascieri (Merck Sharp and Dohme, Rahway, NJ). Crystalline human insulin and recombinant human growth hormone were kindly provided by Eli Lilly Co. (Indianapolis, IN) and Genentech, Inc. (South San Francisco, CA), respectively. $\alpha$ IR-3, a monoclonal antibody highly specific for the type I IGF receptor, was obtained from Oncogene

1. Abbreviations used in this paper: AIB, aminoisobutyric acid; GH, growth hormone; IGFBP, insulin-like growth factor binding protein; SFM, serum-free medium; SV40-HF, simian virus 40-transformed human fibroblasts. 
Science, Inc. (Manhasset, NY). BSA (fraction V, RIA grade) was purchased from Sigma Chemical Co. (St. Louis, MO), and tissue culture media and media supplements were from Gibco Laboratories (Grand Island, NY).

IGFs were iodinated by a modification of the chloramine $\mathrm{T}$ method to a specific activity of $150-300 \mu \mathrm{Ci} / \mu \mathrm{g} \mathrm{(26)}$.

Cell cultures. Dermal fibroblasts from normal adult donors (GM03652A and GM00037D) and SV40-transformed GM00037D cells (GM00637D) were purchased from the Human Genetic Mutant Cell Repository (Camden, NJ). Fibroblasts were cultured in DME supplemented with $100 \mathrm{U} / \mathrm{ml}$ penicillin, $100 \mu \mathrm{g} / \mathrm{ml}$ streptomycin, and 4 $\mathrm{mM}$ glutamine, and containing $10 \%$ supplemented calf serum (HyClone Laboratories, Logan, UT).

Conditioned medium. Cells were detached by trypsinization and plated in 24-multiwells (Costar, Data Packaging Corp., Cambridge, MA). At confluency, fibroblasts were washed twice and preincubated in a 1:1 mixture by volume of Waymouth's medium:DME plus $0.1 \%$ BSA serum-free medium (SFM) for $24 \mathrm{~h}$. The cells were then washed and the medium changed to $0.5 \mathrm{ml} \mathrm{SFM} \pm$ experimental additions for the indicated times. At the end of the incubation period, the conditioned medium was centrifuged at $2000 \mathrm{~g}, 4^{\circ} \mathrm{C}$ for $30 \mathrm{~min}$ and frozen at $-20^{\circ} \mathrm{C}$. At the time of media collection, cell counts were determined on triplicate wells with a Coulter Counter (Coulter Electronics, Hialeah, FL).

Western ligand blots. Unreduced conditioned medium samples $(50$ $\mu 1)$ were processed by SDS-PAGE using a 7.5-15\% linear gradient, and separated proteins were electroblotted onto nitrocellulose filters $(0.45$ $\mu \mathrm{m}$ pore size) using a BioTrans Unit (Gelman Sciences, Ann Arbor, MI). Filters were blocked, labeled with [ $\left.{ }^{125} \mathrm{I}\right] \mathrm{IGF}$ overnight at $4^{\circ} \mathrm{C}$, and visualized by autoradiography, according to the method of Hossenlopp et al. (27). Unstained mol wt standards (BioRad, Richmond, CA) were processed in parallel, and proteins stained using India ink (28). Films were scanned with an UltroScan XL laser densitometer; absorbance curves were integrated and compared, and molecular size determined, using GelScan XL software (Pharmacia LKB Biotechnology Inc., Piscataway, $\mathrm{NJ}$ ).

IGF-I receptor binding. Confluent fibroblast cultures (24-multiwells) were washed twice and the medium changed to SFM with or without IGF-I and [QAYL]IGF-I for $24 \mathrm{~h}$. Cells were then incubated in $2 \mathrm{ml} \mathrm{SFM}$ at $37^{\circ} \mathrm{C}$ for $1 \mathrm{~h}$ (medium changed after $30 \mathrm{~min}$ ) to allow dissociation of reversibly bound peptide (26). [ ${ }^{125}$ I-QAYL]IGF-I binding was performed as described for [ $\left.{ }^{125} \mathrm{I}\right] \mathrm{IGF}-\mathrm{I}$ binding to human fibroblasts $(29,30)$. Monolayers were washed twice with Hepes binding buffer, and incubated with [ $\left.{ }^{125} \mathrm{I}-\mathrm{Q} A Y L\right] I G F-I(25,000 \mathrm{cpm})$ for $2.5 \mathrm{~h}$ at $15^{\circ} \mathrm{C}$. Nonspecific binding, defined as the amount of [ ${ }^{125}$ I-QAYL]IGF bound in the presence of unlabeled IGF-I $(500 \mathrm{ng} / \mathrm{ml})$, was less than $1 \%$ of the total counts added and was subtracted from total binding to determine specific [QAYL]IGF-I binding. [ ${ }^{125}$ I-QAYL]IGF-I binding can be used to determine type I IGF receptor binding without interference by IGFBPs (31).

Thymidine incorporation. Fibroblast monolayers were treated as described above for IGF-I receptor binding. Cells were washed and $\left[{ }^{3} \mathrm{H}\right.$ ] thymidine incorporation measured $22-26 \mathrm{~h}$ after stimulation with $5 \mathrm{nM}$ IGF-I, as detailed in previous publications $(29,32)$.

Aminoisobutyric acid uptake. Fibroblast monolayers were treated as described above for IGF-I receptor binding. Cells were washed and $\left[{ }^{3} \mathrm{H}\right]$ aminoisobutyric acid (AIB) uptake measured $6 \mathrm{~h}$ after stimulation with $2 \mathrm{nM}$ IGF-I, as described previously $(19,29)$.

Affinity cross-linking. Confluent fibroblast cultures (6-multiwell dishes) were preincubated in SFM with or without peptides for $24 \mathrm{~h}$. Cells were acid-washed three times with $0.2 \mathrm{M}$ acetic acid and $0.5 \mathrm{M}$ sodium chloride ( $\mathrm{pH} 2.5$ ) to remove surface bound IGF before binding (33). Monolayers were then washed twice with Hepes binding buffer and incubated with [ $\left.{ }^{125} \mathrm{I}\right] \mathrm{IGF}-\mathrm{I}\left(1.25 \times 10^{6} \mathrm{cpm}\right)$ at $15^{\circ} \mathrm{C}$ for $2.5 \mathrm{~h}$ in the absence or presence of unlabeled IGF-I $(250 \mathrm{ng})$ or insulin $(100 \mu \mathrm{g})$ in a final volume of $1 \mathrm{ml}$. Affinity cross-linking with disuccinimidyl suberate (Pierce Chemical Company, Rockford, IL) was carried out as detailed elsewhere $(30,32)$. Reduced (+100 mM DTT) samples were fractionated by SDS-PAGE. Unstained mol wt standards were processed in parallel. Gels were stained with Coomassie blue, dried, and exposed to Kodak XAR-2 film.

Statistics. Differences between two groups were analyzed using Student's $t$ test for two independent samples. Results were considered statistically significant when $P<0.05$.

\section{Results}

Characterization of IGFBPs secreted by SV40-transformed and normal human fibroblasts: regulation by IGF-I. We incubated SV40-transformed human fibroblasts (SV40-HF) and nontransformed HF with or without hormonal additions, and collected serum-free conditioned medium after $24 \mathrm{~h}$. Fig. 1 shows the migration of IGFBPs after SDS-PAGE of medium samples under nonreducing conditions, transfer of proteins onto nitrocellulose, and incubation with radiolabeled IGF-I. Medium from unstimulated SV40-HF contained IGFBPs with apparent mol wt of $42,38,28$, and $24 \mathrm{kD}$. Western ligand blots of medium conditioned by the untransformed parent line also showed bands at $42,38,28$, and $24 \mathrm{kD}$, with additional bands at 36 and $32 \mathrm{kD}$. When [125 I]IGF-II was employed as the radioligand, the only major change was the appearance of a diffuse band at 30-32 kD in both SV40-transformed and untransformed cell-conditioned media, indicating an IGF-II-preferring IGFBP of this mol wt (data not presented). The 42/38-kD IGF binding doublet in human fibroblast conditioned medium comigrates with purified IGFBP-3 (13). The two bands are encoded by a single gene and are believed to represent glycosylation variants of IGFBP-3 $(7,8,19,34)$. By densitometric analyses of autoradiograms from six experiments, normal HF appeared to secrete (mean \pm SE) $8 \pm 2$-fold more IGFBP-3 than their SV40-transformed counterpart; this was inspite of a 4fold greater cell number in the SV40-HF cultures at the time of
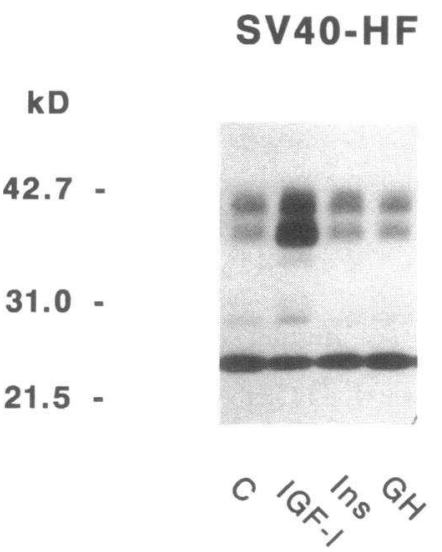

Normal HF

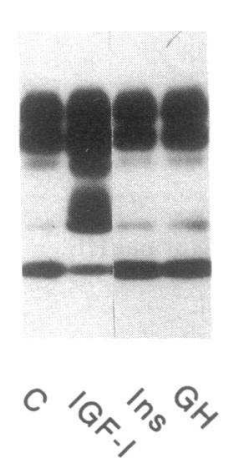

Figure 1. Western ligand blot of IGFBPs in culture medium conditioned by normal and transformed adult human fibroblasts. SV40-HF and the nontransformed parent cell line, GM00037D (normal HF), were incubated $24 \mathrm{~h}$ in SFM without (control, $C$ ) or with IGF-I (10 $\mathrm{nM})$, insulin (Ins, $1,000 \mathrm{nM})$, or $\mathrm{GH}(1 \mu \mathrm{g} / \mathrm{ml})$. Conditioned medium samples $(50 \mu \mathrm{l})$ were electrophoresed through a nonreducing SDS-polyacrylamide gel (7.5-15\% linear gradient) and separated proteins transferred onto nitrocellulose; after incubation with [ ${ }^{125}$ I]IGF-I, filter-immobilized IGFBPs were identified by autoradiography, as described in Methods. The migration positions of unstained molecular size markers are indicated on the left. 
media collection $\left(3.76 \pm 0.53 \times 10^{5}\right.$ cells vs. $0.87 \pm 0.13 \times 10^{5}$ cells).

IGF-I (10 nM) increased levels of IGFBP-3 in medium from SV40-HF and normal HF cultures (Fig. 1 and Table I). As was more evident in the SV40-HF cells, IGF-I preferentially increased the 38-kD IGFBP-3 form (7-fold) over the 42-kD form (2.5-fold). IGF-I also increased 28-32-kD IGFBPs, and induced the appearance of a 36-kD IGFBP in these cells. Incubation with IGF-I had no significant effect on the 24-kD IGFBP form secreted by SV40-HF. The small increase in SV40-HF cell number with IGF-I treatment $(122 \pm 7 \%$; mean $\pm \mathrm{SE}, n=9$ ) was inadequate to account for the marked changes in secreted IGFBP-3 and $36 \mathrm{kD}$ IGFBP. Furthermore, insulin $(1,000 \mathrm{nM})$ had equivalent stimulatory effects on SV40-HF replication $(122 \pm 14 \%, n=5)$, but had no effect on IGFBP secretion. In normal adult HF (Fig. 1 and Table I), addition of IGF-I (10 nM) caused smaller relative increases in 38-kD (210\%) and 42-kD (139\%) IGFBP-3 forms. In these cells, IGF-I increased the 28- and 36-kD IGFBPs threefold and fivefold, respectively, and decreased levels of the 24-kD IGFBP by $80 \%$. The $30-32-k D$ IGF-II-preferring IGFBP was also increased $50-100 \%$ by IGF-I treatment of SV40-HF and normal $\mathrm{HF}$, as assessed by Western ligand blotting of the medium with radiolabeled IGF-II (data not presented). In three separate dose-response experiments, an effect of IGF-I to alter IGFBP release in normal $\mathrm{HF}$ and SV40-HF was evident at $0.1-1 \mathrm{nM}$ IGF-I, and maximal at $~ 5 \mathrm{nM}$ IGF-I; insulin at $0.1-1,000 \mathrm{nM}$ had no effect (data not shown). GH $(1 \mu \mathrm{g} / \mathrm{ml})$ had little or no

Table I. IGFBPs in the Medium of Human Fibroblasts Treated with IGF-I, Insulin, and GH

\begin{tabular}{lccc}
\hline & \multicolumn{3}{c}{ IGFBP band intensity } \\
\hline$k D$ & & $\%$ of control & \\
IGFBP & & & \\
SV40-HF & IGF-I (9) & Insulin (7) & GH (3) \\
42 & & & $118 \pm 10$ \\
38 & $255 \pm 26^{\ddagger}$ & $105 \pm 7$ & $138 \pm 20$ \\
36 & $695 \pm 76^{8}$ & $95 \pm 7$ & - \\
28 & + & - & $117 \pm 10$ \\
24 & $196 \pm 16^{8}$ & $122 \pm 18$ & $106 \pm 4$ \\
& $107 \pm 5$ & $104 \pm 4$ & \\
Normal HF & & & GH (3) \\
42 & IGF-I (6) & Insulin (4) & $119 \pm 9$ \\
38 & $139 \pm 14^{*}$ & $115 \pm 8$ & $120 \pm 4^{\ddagger}$ \\
36 & $211 \pm 33^{*}$ & $96 \pm 11$ & $111 \pm 17$ \\
28 & $516 \pm 86^{\ddagger}$ & $104 \pm 19$ & $113 \pm 13$ \\
24 & $308 \pm 86^{\ddagger}$ & $104 \pm 6$ & $100 \pm 11$ \\
& $21 \pm 5^{\S}$ & $118 \pm 7$ & \\
\hline
\end{tabular}

Cells were treated and IGFBPs analyzed by Western ligand blotting, as described in Fig. 1. Values represent scanning densitometric data of IGFBP bands from $(n)$ experiments. For each experiment, at least two exposures were taken to optimize analysis of the different IGFBP species. Data from GM00037D and GM03652 are included for normal HF. Results (mean \pm SE) are expressed as the percentage change in band intensity compared with control (100\%). Induction of an IGFBP species (i.e., no band in control) is indicated by $+.{ }^{*},{ }^{*},{ }^{8} \mathrm{Val}-$ ues significantly different from control at $P<0.05, P<0.01$, and $P$ $<0.001$, respectively. effect on IGFBP secretion in SV40-HF (Fig. 1 and Table I). In normal adult human fibroblasts there was a small but significant increase in 38-kD IGFBP-3 with GH treatment, in agreement with our earlier report (24). GH did not block IGF-I-induced changes in IGFBP secretion in these cells (data not shown). The relative changes in the different IGFBP species with IGF-I, insulin, and GH treatment of SV40-HF and normal HF cultures are given in Table $I$.

These data indicate that IGF-I is a major regulator of its own binding proteins in normal and SV40-transformed HF cultures. We next investigated the mechanism(s) of the IGF-Iassociated increase in IGFBPs in these cells.

Is the IGF-I-specific increase in IGFBP a receptor-mediated event? As shown in Fig. 2, SV40-HF released IGFBPs into the medium with time in culture. The addition of IGF-I (10 nM) resulted in increased levels of IGFBP-3 and induced 36-kD IGFBP at each time period. A preferential 4.5-fold increase in the 38-kD IGFBP-3 form was apparent at $6 \mathrm{~h}$; IGF-I increased 38-kD IGFBP-3 five to eightfold and 42-kD IGFBP-3 approximately twofold with longer incubations (24-72 h). Insulin $(1,000 \mathrm{nM})$ did not mimic IGF-I's effects on IGFBP production by SV40-HF. Similar time course results with IGF-I and insulin were obtained in normal HF (data not shown). Insulin at high concentrations does not bind to IGFBPs but can crossreact with the type I IGF receptor and act as an IGF-I surrogate $(2,26,30)$. Thus, these data suggested that the IGF-I-stimulated increase in IGFBPs might not be receptor-mediated. In concordance with this, $\alpha$ IR-3, a monoclonal antibody that inhibits IGF-I binding and receptor-mediated action in human fibroblasts $(29,32)$, inhibited IGF-I receptor binding but failed to block the IGF-I-induced changes in IGFBPs in normal HF and SV40-HF media (Fig. 3). Furthermore, there were major differences in the ability of IGF-I, IGF-II, and different IGF-I analogues to stimulate IGFBP secretion (Figs. 4 and 5). IGF-II, [ser $\left.{ }^{24}\right]$ IGF-I, and $\left[1-27, \mathrm{Gly}_{4}, 38-70\right]$ IGF-I, IGFs that bind normally to IGFBPs but have 10-, 16-, and 30-fold reduced affinity, respectively, for the type I IGF receptor $(32,35,36)$, were able to increase IGFBP-3 and the 36-kD IGFBP in SV40-HF medium in a dose-dependent manner comparable to native IGF-I. IGF-I, IGF-II, [ $\operatorname{ser}^{24}$ ]IGF-I, and [1-27, Gly 4 , 38-70]IGF-I all preferentially increased the $38-\mathrm{kD}$ IGFBP-3 form. In comparison, treatment of SV40-HF with [QAYL]IGF-I, a mutant IGF-I with normal type I and type II IGF receptor binding but

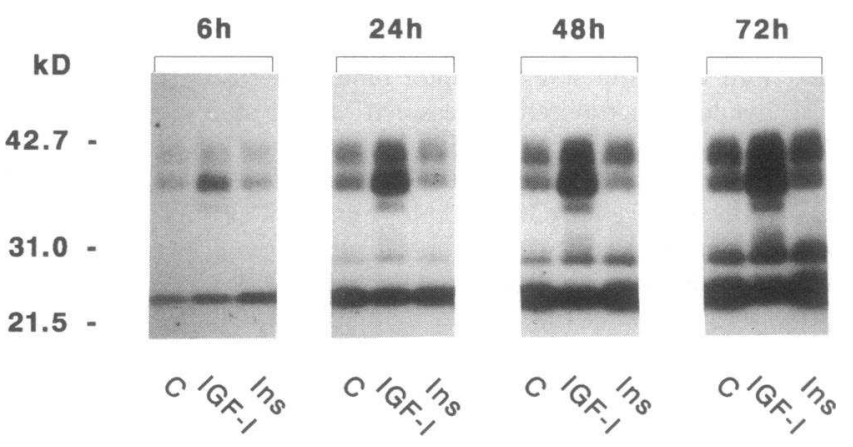

Figure 2. Western ligand blot of IGFBPs: time course of IGF-I and insulin (Ins) stimulation. Conditioned medium samples from SV40HF cultures incubated for the indicated times without (control, $C$ ) or with $10 \mathrm{nM}$ IGF-I or $1,000 \mathrm{nM}$ insulin were analyzed by Western blotting with [ ${ }^{125}$ I]IGF-I, as described in Fig. 1. 


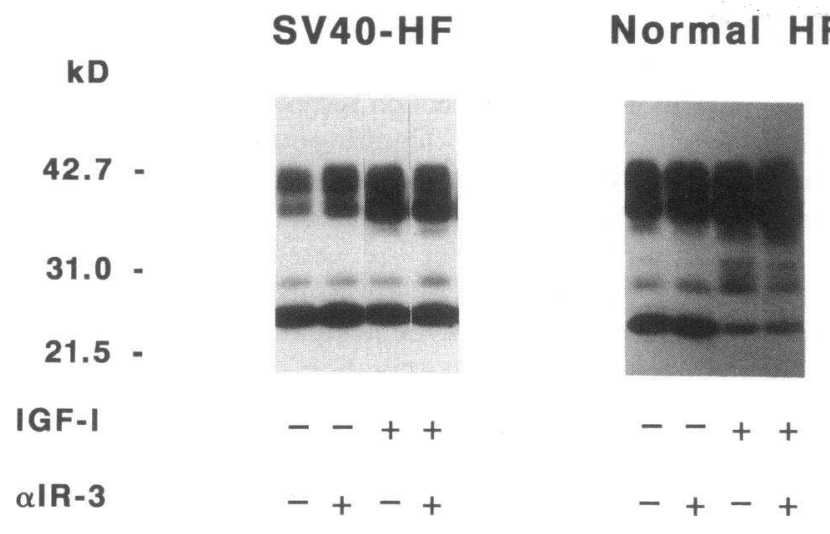

Figure 3. Western ligand blot of IGFBPs: effect of $\alpha$ IR-3. SV40-HF were pretreated $1 \mathrm{~h}$ with or without $20 \mathrm{nM} \alpha \mathrm{IR}-3$, and then IGF-I ( $1 \mathrm{nM}$ ) was added to the SFM for $24 \mathrm{~h}$. Normal HF (GM03652A) were pretreated $1 \mathrm{~h} \pm 50 \mathrm{nM} \alpha \mathrm{IR}-3$, and then $5 \mathrm{nM}$ IGF-I was added to the SFM for $24 \mathrm{~h}$. The conditioned medium samples were analyzed by Western blotting with [ $\left.{ }^{125} \mathrm{I}\right] \mathrm{IGF}-\mathrm{I}$, as described in Fig. 1 . These experiments were repeated twice with similar results. Under these conditions, $\alpha$ IR-3 inhibited [ ${ }^{125}$ I-QAYL]IGF-I binding to normal HF and SV40-HF monolayers $85-90 \%$. [ ${ }^{125}$ I-QAYL]IGF-I binding is a specific measure of type I IGF receptor binding (31).

with 600-fold reduced affinity for IGFBPs (37), had little effect on IGFBP secretion. The relative changes in medium $38-\mathrm{kD}$ IGFBP-3 induced by incubation of SV40-HF with IGF-I and the different IGF analogues are presented in Fig. 5. Comparable change in IGFBP-3 and 36-kD IGFBP with the different IGFs were seen in normal HF. In these cells, however, the potency of the different IGF preparations in decreasing 24-kD

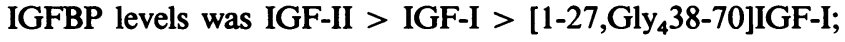
[QAYL]IGF-I was without effect.

These data indicate that IGF-I-associated increases in IGFBPs in SV40-HF and normal adult HF are not due to type I IGF receptor-mediated stimulation of IGFBP synthesis.

Soluble IGFBP prevents ligand-induced receptor downregulation. What could be the physiological significance of an acute increase in soluble IGFBPs in the microenvironment as a direct response to IGF-I? One possibility might be as a means to
SV40-HF

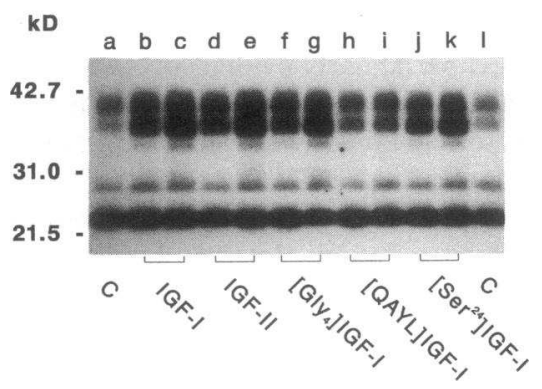

Normal HF

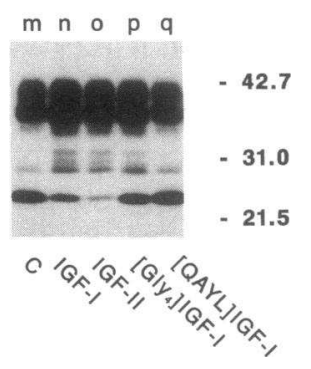

Figure 4. Western ligand blot of IGFBPs: regulation by native IGFs and IGF-I analogues. SV40-HF (left) and normal HF (GM00037D; right) were incubated without (control, $C$, lanes $a, l, m$ ) or with IGF-I, IGF-II, [1-27, Gly 4 , 38-70]IGF-I, [QAYL]IGF-I, or [ $\operatorname{ser}^{24}$ ]IGF-I at 1 nM (lanes $b, d, f, h, j$ ) or $10 \mathrm{nM}$ (lanes $c, e, g, i, k, n-q)$. 24-h conditioned medium samples were analyzed by Western ligand blotting with [ ${ }^{125}$ I]IGF-I as described in Fig. 1.

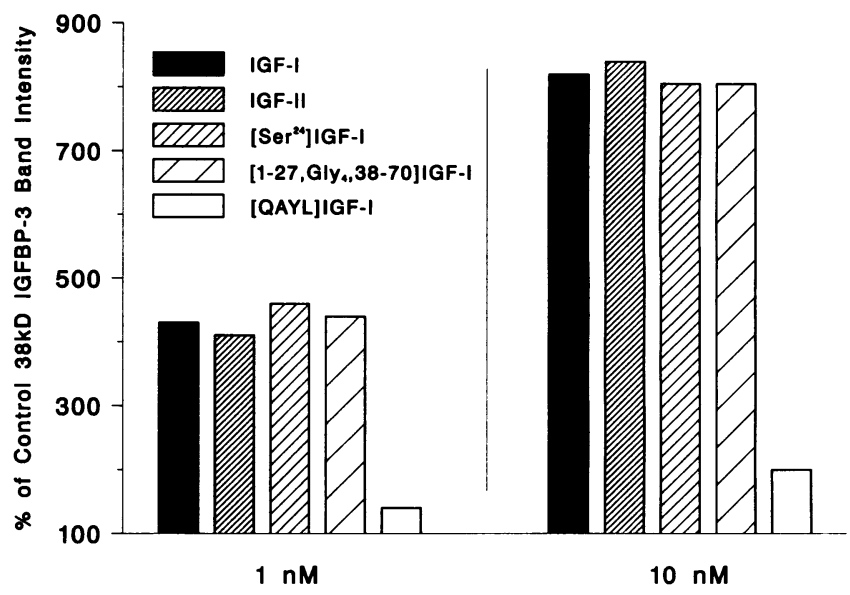

Figure 5. Effect of native IGFs and IGF-I analogues on 38-kD IGFBP-3 levels in human fibroblast conditioned medium. Cells were treated as described in Fig. 4. Values represent scanning densitometric analyses of the 38-kD IGFBP-3 bands in two experiments, expressed as the percentage change in band intensity compared with control $(100 \%)$.

protect certain cell types from ligand-induced receptor downregulation, a process that renders cells refractory to further IGF-I stimulation. We explored this idea in the following series of experiments. SV40-HF and normal HF were incubated for $24 \mathrm{~h}$ with $0.5 \mathrm{nM}$ and $1 \mathrm{nM}$ IGF-I (which increases soluble IGFBP) or [QAYL]IGF-I (which does not). Cells were washed to remove reversibly bound ligand, and [ $\left.{ }^{125} \mathrm{I}-\mathrm{QAYL}\right]-$ IGF-I binding performed. The use of this radiolabeled IGF-I permits determination of type I receptor binding on cells independent of the presence of IGFBPs (31). As shown in Fig. $6 \mathrm{~A}$, a 24-h preincubation with [QAYL]IGF-I caused a dose-dependent decrease in [ ${ }^{125} \mathrm{I}-\mathrm{QAYL}$ ] IGF-I binding to SV40-HF and normal HF. With $1 \mathrm{nM}$ [QAYL]IGF-I, receptor binding was $55-60 \%$ of maximum. In comparison, preincubation with 0.5 $\mathrm{nM}$ or $1 \mathrm{nM}$ IGF-I did not affect [ ${ }^{125} \mathrm{I}-\mathrm{QAY}$ L]IGF-I binding to normal HF and SV40-HF.

[ ${ }^{125} \mathrm{I}-\mathrm{QAYL}$ ]IGF-I binding, a measure of receptor availability, reflected changes in cell surface receptor number as shown in Fig. 7. For these experiments, SV40-HF were preincubated with IGF-I $(1,10 \mathrm{nM})$ or insulin $(1,000 \mathrm{nM})$ for $24 \mathrm{~h}$. Insulin at high concentrations binds to the type I receptor but not to IGFBPs, properties similar to [QAYL]IGF-I (37). Monolayers were then washed to remove surface bound IGF-I before affinity cross-linking with [ $\left.{ }^{125} \mathrm{I}\right] \mathrm{IGF}-\mathrm{I}$. When cells were preincubated for $24 \mathrm{~h}$ in SFM alone, we observed major affinity-labeled bands (reducing conditions) at 132 and $36-50 \mathrm{kD}$. Labeling of the $132-\mathrm{kD}$ band was inhibited by unlabeled IGF-I (125 $\mathrm{ng})$ and insulin $(100 \mu \mathrm{g})$; this band corresponds to the alpha binding subunit of the type I IGF receptor described in a variety of cells, including human fibroblasts $(30,32,38)$. Labeling of the lower mol wt bands was inhibited by unlabeled IGF-I but not by high concentrations of insulin, indicating cell surfaceassociated IGFBPs. In four experiments, one of which is presented in Fig. 7, a 24-h preincubation with $10 \mathrm{nM}$ IGF-I decreased labeling of the $132-\mathrm{kD}$ band (mean $\pm \mathrm{SE}$ ) $53 \pm 4 \%$; treatment with high concentrations of insulin decreased labeling $64 \pm 4 \%$. Preincubation with $1 \mathrm{nM}$ IGF-I did not alter 132-kD band intensity. Labeling of membrane-associated IGFBPs was 


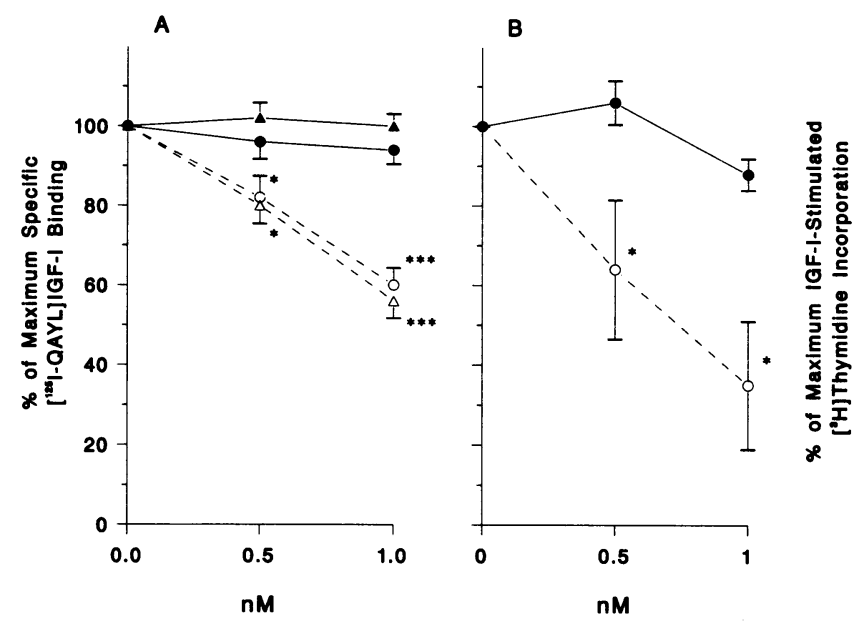

Figure 6. Human fibroblast receptor binding and cell responsiveness to IGF-I stimulation: preincubation with IGF-I and [QAYL]IGF-I. Normal HF $(\infty)$ and SV40-HF $(\Delta \Delta)$ were preincubated for $24 \mathrm{~h}$ in SFM with $0,0.5$, and $1 \mathrm{nM}$ IGF-I (closed symbols) or [QAYL]IGF-I (open symbols). Cultures were then incubated at $37^{\circ} \mathrm{C}$ with SFM for $60 \mathrm{~min}$ before measurements of binding and thymidine incorporation. $(A)$ Binding of [ ${ }^{125} \mathrm{I}-\mathrm{QAY}$ L]IGF-I to monolayer cultures of SV40-HF and normal HF was performed as described in Methods. Results (mean $\pm \mathrm{SE}$ of three or four experiments) are expressed as a percentage of maximum specific binding (no additions during preincubation $=100 \%) .(B)\left[{ }^{3} \mathrm{H}\right]$ Thymidine incorporation was measured in normal HF (GM00037D and GM03652) 22-26 h after addition of $5 \mathrm{nM}$ IGF-I. Results (mean \pm SE of three experiments) are expressed as a percentage of maximum IGF-I stimulation (no additions during preincubation $=100 \%) .\left({ }^{* * * * *}\right)$ A significant difference between IGF-I and [QAYL]IGF-I preincubations at $P<0.05$ and $P<0.001$, respectively.

unaffected by preincubation with IGF-I, certifying the efficacy of the wash procedure to remove unlabeled IGF-I before binding. In other experiments (not shown), 24-h preincubation with $2 \mathrm{nM}$ [QAYL]IGF-I also resulted in diminished labeling of the

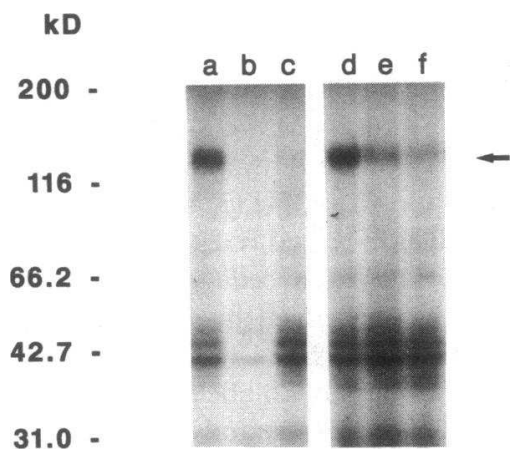

Figure 7. Autoradiogram of [ $\left.{ }^{125}\right]$ IGF-I cross-linked to SV40-HF monolayers: preincubation with IGF-I. SV40-HF were incubated 24 $\mathrm{h}$ in SFM without (lanes $a-c$ ) or with $1 \mathrm{nM}$ IGF-I (lane $d$ ), $10 \mathrm{nM}$ IGF-I (lane $e$ ), or $1,000 \mathrm{nM}$ insulin (lane $f$ ). The monolayers were washed to remove reversibly bound ligand before $\left[{ }^{125}\right.$ I]IGF-I binding and cross-linking in the absence or presence of unlabeled IGF-I (lane $b$ ) and insulin (lane $c$ ), as described in Methods. Solubilized complexes (+DTT) were separated by 5-15\% gradient SDS-PAGE. Migration positions of unstained molecular size markers are shown on the left. The arrow indicates the $132-\mathrm{kD}$ band.
132-kD band. Competitive binding experiments demonstrated that preincubation with [QAYL]IGF-I or high concentrations of insulin or IGF-I had no effect on receptor affinity. $50 \%$ displacement of [ ${ }^{125} \mathrm{I}-\mathrm{QAY}$ L]IGF-I binding occurred at $\sim 0.6 \mathrm{nM}$ unlabeled IGF-I or [QAYL]IGF-I and $600 \mathrm{nM}$ insulin under both normal and preincubation conditions (data not shown).

Changes in receptor availability were reflected in cell responsiveness to IGF-I (Fig. $6 \mathrm{~B}$ ). Preincubation with [QAYL]IGF-I for $24 \mathrm{~h}$ caused a dose-dependent decrease in IGF-Istimulated $\left[{ }^{3} \mathrm{H}\right]$ thymidine incorporation in normal HF; after exposure to $1 \mathrm{nM}$ [QAYL]IGF-I, cell responsiveness was only $35 \%$ of control. This relatively resistant state was also seen after a 48-h preincubation period and persisted for more than $24 \mathrm{~h}$ after removal of the [QAYL]IGF-I (data not shown). In contrast, preincubation with equivalent concentrations of IGF-I had no significant effect on subsequent cell responsiveness to IGF-I. IGF-I-stimulated $\left[{ }^{3} \mathrm{H}\right] \mathrm{AIB}$ uptake in human fibroblasts was also impaired after preincubation with $1 \mathrm{nM}$ [QAYL]IGFI $(62 \pm 5 \%$ of maximum stimulation, $n=3, P<0.05)$, whereas cells maintained responsiveness to IGF-I after incubation for $24 \mathrm{~h}$ with $1 \mathrm{nM}$ IGF-I $(91 \pm 5 \%$ of maximum stimulation, $P=$ NS).

\section{Discussion}

IGF-I stimulates a marked increase in IGFBPs in the medium of normal and SV40-transformed human fibroblasts, independent of type I IGF receptor binding. The results of these in vitro studies reflect observations of IGF-I-associated changes in IGFBPs in vivo (10-12), and provide a possible mechanism to explain why extracellular fluid concentrations of IGF-I and specific IGFBPs are coordinated. Furthermore, our physiological studies suggest that direct IGF-I alteration of IGFBP availability provides a unique mechanism for modulating cellular responsiveness to IGF-I.

Human fibroblast IGFBPs: regulation by IGF-I. The IGFBPs identified in human fibroblast conditioned medium (with apparent mol wt of 42/38, 36, 30-32, 28, and $24 \mathrm{kD}$ ) correspond to specific forms found in human serum $(39,40)$.

The 42/38-kD doublet represents glycosylation variants of IGFBP-3 (34). As demonstrated in this study, IGF-I increased 42/38-kD IGFBP-3 in the media of normal HF and SV40-HF, whereas GH had little or no effect. These results support the proposal put forth by us (13) and by others $(10,11,17)$ that the apparent GH-dependency of IGFBP-3 is mediated in large part by IGF-I. IGF-I's effect was particularly evident in SV40-HF cultures, which have low levels of medium IGFBP-3 in the unstimulated state. In these cells, there was a preferential increase in the $38-\mathrm{kD}$ (7-fold) over the $42-\mathrm{kD}$ (2.5-fold) IGFBP-3 variant, suggesting that degree of glycosylation may be an important characteristic of this regulation. Relative increases in 38- and 42-kD IGFBP-3 with the addition of IGF-I to normal HF cultures were 210 and $140 \%$, respectively; the diminished sensitivity presumably reflecting the high basal secretion of IGFBP- 3 by these cells. The absolute increase in IGFBP-3 in the medium supplemented with IGF-I may be similar in both normal and SV40-HF fibroblast systems, however. Martin and Baxter also reported an increase in IGFBP-3 with IGF-I in neonatal human fibroblasts (15). These results in cultured human fibroblasts correspond to in vivo studies where infusion of hypophysectomized and diabetic rats and healthy man with 
IGF-I resulted in increased circulating IGFBP-3 $(10,12)$. Also, circulating levels of IGF-I and IGFBP-3 change in parallel under a variety of pathophysiological conditions (11). It may be relevant that within the plasma $150-\mathrm{kD}$ IGFBP-3 complex, the $38-\mathrm{kD}$ IGFBP-3, but not the $42-\mathrm{kD}$, form decreases with age (41). Thus, normal HF and SV40-HF provide versatile models for examining possible underlying mechanism(s) for IGF-I regulation of IGFBP-3.

We also found that treatment of SV40-HF and normal HF with IGF-I resulted in increased 36-kD IGFBP, and had signifcant stimulatory effects on IGFBPs with mol wt in the range of 28-32 kD. In addition, IGF-I markedly decreased 24-kD IGFBP in normal HF. The specific identities of these IGF-Iregulated IGFBPs were not determined in this study. Nevertheless, our observations may be related to other in vivo and in vitro studies. IGF-I-"inducible" 28-32-kD IGFBPs have been described in fetal and neonatal human fibroblast cultures (15, 42), rat osteoblast-like cells (18), rodent muscle cells (14), and rabbit articular chondrocytes (16). The 36-kD IGFBP may represent $36-\mathrm{kD}$ human IGFBP-2, which is increased in plasma during subcutaneous infusion of IGF-I in healthy adults (12). However, in contrast to results in vivo where the increase is prevented by simultaneous $\mathrm{GH}$ administration (12), GH in our study had no effect on basal or IGF-I-stimulated increases in IGFBPs. This difference in modulation by GH may indicate an indirect effect of $\mathrm{GH}$ in vivo. On the other hand, the $36-\mathrm{kD}$ IGFBP in human fibroblast conditioned medium may be related to IGFBP-3, because these two forms appear to respond in concert to IGF-I. The 24-kD IGFBP most likely relates to IGFBP-4 purified from rat serum and human bone cell-conditioned medium $(9,43)$. The IGF-I-associated decrease in 24$\mathrm{kD}$ IGFBP described here in normal adult HF has also been reported by Clemmons et al. in human fetal fibroblasts (44). In our study, IGF-II was twice as effective as IGF-I in decreasing medium levels of 24-kD IGFBP. We did not observe a decrease in 24-kD IGFBP with IGF-I or IGF-II in SV40-HF cultures, and the potential significance of these differing results with transformation is unclear.

Mechanism: receptor-independent. Many peptide hormones have been shown to regulate IGFBP secretion through receptor-mediated changes in gene expression (45-47). Our findings are unique in this respect, and our conclusion that IGF-I-associated increases in IGFBPs in human fibroblasts are independent of IGF-I receptor interaction is supported by the following observations: $(a)$ insulin at high concentrations can cross-react with the type I IGF receptor in these cells, but had no effect on IGFBP secretion; (b) downregulation of the type I IGF receptor did not diminish IGF-I-induced increases in IGFBP release; $(c)$ incubation of human fibroblasts with IGF-II and IGF-I analogues having reduced affinities for the type I IGF receptor resulted in dose-dependent increases in medium IGFBP, equivalent to those seen with IGF-I; $(d)$ [QAYL]IGF-I, a mutant IGF-I that binds normally to the type I IGF receptor but has 20- to 600-fold reduced affinity for IGFBPs, failed to stimulate an increase in medium IGFBPs; and (e) $\alpha \mathrm{IR}-3$, a monoclonal antibody that blocks IGF-I binding to its receptor, did not block IGF-I-induced increases in IGFBPs. Thus, IGF-I does not influence IGFBP availability by regulating IGFBP synthesis in these cells. We are currently exploring alternative mechanisms involving direct interaction of IGF peptide with secreted IGFBP.
This is the first report to examine and define an IGF-I receptor-independent mechanism for IGFBP regulation; however, our findings are not without precedent. These results might have been anticipated from the observation of Clemmons et al. that IGF-I stimulation of 31-kD IGFBP secretion in human fetal fibroblasts depended more upon IGF-I binding to the binding protein and less on IGF-I receptor association (44). Along the same lines, in a study by Martin and Baxter (15), IGF-I stimulated an increase in a 29-31-kD IGFBP doublet in neonatal HF medium, and this effect was not mimicked with high concentrations of insulin, consistent with a receptor-independent effect of IGF-I on this IGFBP. This mechanism may also account for IGF-I-induced increases in IGFBP-3 in rat and human osteoblast-like cultures, which are not related to changes in IGFBP-3 gene expression (reference 48, and our unpublished observations). However, not all IGF-I-stimulated increases in IGFBPs appear to be receptor-independent. In cultured bovine fibroblasts, IGF-I induces IGFBP-3 synthesis (reference 13, and our unpublished observations). Studies by McCusker et al. also suggested that IGF-I-stimulated IGFBP secretion (31- and 24-kD forms) in $\mathrm{L} 6$ and $\mathrm{BC}_{3} \mathrm{H}-1$ cells was mediated via the type I IGF receptor (14).

Physiological significance. What are the possible physiological implications of a receptor-independent mechanism allowing for a rapid increase in soluble IGFBP in the microenvironment as a direct response to IGF-I? Many peptide hormones, including IGF-I, insulin, and GH are able to induce a decrease in the number of their cell-surface receptors (downregulation), rendering the cells refractory to further stimulation $(26,49)$. Insulin and $\mathrm{GH}$ are secreted in a pulsatile fashion and generally circulate at low levels. Total circulating IGF concentrations, on the other hand, are high and relatively invariable (50) and could result in extensive downregulation of the type I IGF receptor based upon in vitro studies (26). However, the $150-\mathrm{kD}$ IGFBP complex in serum restricts access of IGFs to the extravascular spaces and prevents the insulin-like effects of excess IGFs $(10,39)$; a similar role may exist for cell-derived IGFBPs. We and others have shown that soluble IGFBPs can prevent IGF-I receptor interaction (19-21). In this study, we demonstrated that incubation of normal HF and SV40-HF with an IGF-I analogue unable to increase soluble IGFBPs, but having normal type I IGF receptor binding, occupied and downregulated the receptor more effectively than native IGF-I. This downregulation of the type I IGF receptor was paralleled by decreased responsiveness of the cells to subsequent IGF-I stimulated DNA synthesis and amino acid uptake. Moreover, addition of pure IGFBP-3 blocks IGF-I-induced receptor downregulation and cell desensitization in cultured bovine fibroblasts (51). Ernst and Rodan also showed that enhanced IGF-I-stimulated DNA and collagen synthesis correlated with accumulation of IGFBP-3 in the culture medium (52). Therefore, an acute increase in soluble IGFBPs, especially IGFBP-3, may be a "reflex" response of specific cells to changes in local IGF-I levels, allowing continued cell responsiveness.

In addition, an increase in soluble IGFBPs may capture and retain the IGF-I peptide in the cell microenvironment, and act as a time-release complex. Blum et al. reported that addition of IGFBP-3 enhanced IGF-I-stimulated thymidine incorporation in baby hamster kidney fibroblasts (53). Although cell surface association was not determined in their study, it is conceivable that IGF-I activates or facilitates IGFBP-3 attachment to spe- 
cific cell membranes. This process would be analogous to the assembling of the $150-\mathrm{kD}$ plasma complex, i.e., the acid-labile subunit binds only IGFBP-3 complexed with IGF (54).

Thus, IGF-I regulates the availability of IGFBPs in cultured human fibroblasts by a unique receptor-independent mechanism. Changes in levels of soluble IGFBPs, in turn, modulate IGF-I peptide and receptor interaction and may constitute an important level of control in IGF cellular physiology. Further studies are needed to characterize this mechanism, and to determine its contribution to IGF pathophysiology and its implication in the clinical use of IGFs.

\section{Acknowledgments}

I would like to thank Laurie Bale and Jay Clarkson for their excellent technical assistance.

This work was supported by the Mayo Foundation.

\section{References}

1. Froesch, E. R., C. Schmid, J. Schwander, and J. A. Zapf. 1985. Actions of insulin-like growth factors. Rev. Physiol. Biochem. Pharmacol. 47:443-467.

2. Baxter, R. C., and J. L. Martin. 1989. Binding proteins for the insulin-like growth factors: structure, regulation and function. Prog. Growth Factor Res. 1:49-68.

3. Lee, Y.-L., R. L. Hintz, P. M. James, P. D. K. Lee, J. E. Shively, and D. R. Powell. 1988. Insulin-like growth factor (IGF) binding protein complementary deoxyribonucleic acid from human $H E P \mathrm{G}_{2}$ hepatoma cells: predicted protein sequence suggests an IGF binding domain different from those of the IGF-I and IGF-II receptors. Mol. Endocrinol. 2:404-411.

4. Luthman, H., J. Soderling-Barros, B. Persson, C. Engberg, I. Stern, M. Lake, S.-A. Franzen, M. Israelsson, B. Raden, B. Lindgren, L. Hjelmqvist, S. Enerback, P. Carlsson, G. Bjursell, G. Pavoa, K. Hall, and H. Jornvall. 1989. Human insulin-like growth-factor-binding protein. Low-molecular-mass form: protein sequence and cDNA cloning. Eur. J. Biochem. 180:259-265.

5. Binkert, C., J. Landwehr, J.-L. Mary, J. Schwander, and G. Heinrich. 1989. Cloning, sequence analysis and expression of a cDNA encoding a novel insulinlike growth factor binding protein (IGFBP-2). EMBO (Eur. Mol. Biol. Organ.) J. 8:2497-2502.

6. Brown, A. L. L. Chiariotti, C. C. Orlowski, T. Mehlman, W. H. Burgess, E. J. Ackerman, C. B. Bruni, and M. M. Rechler. 1989. Nucleotide sequence and expression of a cDNA clone encoding a fetal rat binding protein for insulin-like growth factors. J. Biol. Chem. 264:5148-5154.

7. Wood, W. I., G. Cachianes, W. J. Henzel, G. A. Winslow, S. A. Spencer, R. Hellmiss, J. Martin, and R. C. Baxter. 1988. Cloning and expression of the growth hormone-dependent insulin-like growth factor-binding protein. Mol. Endocrinol. 2:1176-1185.

8. Shimasaki, S., A. Koba, M. Mercado, M. Shimonaka, and N. Ling. 1989. Complementary DNA structure of the high molecular weight rat insulin-like growth factor binding protein (IGFBP-3) and tissue distribution of its mRNA. Biochem. Biophys. Res. Commun. 165:907-912.

9. Shimasaki, S., F. Uchiyama, M. Shimonaka, and N. Ling. 1990. Molecular cloning of the cDNAs encoding a novel insulin-like growth factor-binding protein from rat and human. Mol. Endocrinol. 4:1451-1458.

10. Zapf, J., C. Hauri, M. Waldvogel, E. Futo, H. Hasler, K. Binz, H. P. Guler, C. Schmid, and E. R. Froesch. 1989. Recombinant human insulin-like growth factor I induces its own specific carrier protein in hypophysectomized and diabetic rats. Proc. Natl. Acad. Sci. USA. 86:3813-3817.

11. Hardouin, S., M. Gourmelen, P. Noguiez, D. Seurin, M. Roghani, Y. Le Bouc, G. Povoa, T. J. Merimee, P. Hossenlopp, and M. Binoux. 1989. Molecular forms of serum insulin-like growth factor (IGF)-binding proteins in man: Relationships with growth hormone and IGFs and physiological significance. J. Clin. Endocrinol. Metab. 69:1291-1301.

12. Zapf, J., C. Schmid, H. P. Guler, M. Waldvogel, C. Hauri, E. Futo, P. Hossenlopp, M. Binoux, and E. R. Froesch. 1990. Regulation of binding proteins for insulin-like growth factors (IGF) in humans: increased expression of IGF binding protein 2 during IGF-I treatment of healthy adults and in patients with extrapancreatic tumor hypoglycemia. J. Clin. Invest. 86:952-961.

13. Conover, C. A. 1990. Regulation of insulin-like growth factor (IGF) binding protein synthesis by insulin and IGF-I in cultured bovine fibroblasts. Endocrinology. 126:3139.

14. McCusker, R. H., C. Camacho-Hubner, and D. R. Clemmons. 1989.
Identification of the types of insulin-like growth factor-binding proteins that are secreted by muscle cells in vitro. J. Biol. Chem. 264:7795-7800.

15. Martin, J. L., and R. C. Baxter. 1990. Production of an insulin-like growth factor (IGF)-inducible IGF-binding protein by human skin fibroblasts. Endocrinology. 127:781-788.

16. Froger-Gaillard, B., P. Hossenlopp, M. Adolphe, and M. Binoux. 1989 Production of insulin-like growth factors and their binding proteins by rabbit articular chondrocytes: relationship with cell multiplication. Endocrinology. 124:2365-2372.

17. Smith, E. P., B. A. Dickson, and S. D. Chernausek. 1990. Insulin-like growth factor binding protein-3 secretion from cultured rat sertoli cells: dual regulation by follicle stimulating hormone and insulin-like growth factor-I. Endocrinology. 127:2744-2751.

18. Schmid, C., J. Zapf, and E. R. Froesch. 1989. Production of carrier proteins for insulin-like growth factors (IGFs) by rat osteoblastic cells. FEBS (Fed. Eur. Biochem. Soc.) Lett. 244:328-332.

19. Conover, C. A., M. Ronk, F. Lombana, and D. R. Powell. 1990. Structural and biological characterization of bovine insulin-like growth factor binding protein-3. Endocrinology. 127:2795-2803.

20. Ritvos, O., T. Ranta, J. Jalkanen, A.-M. Suikkari, R. Voutilainen, H. Bohn, and E.-M. Rutanen. 1988. Insulin-like growth factor (IGF) binding protein from human decidua inhibits the binding and biological action of IGF-I in cultured choriocarcinoma cells. Endocrinology. 122:2150-2157.

21. Gopinath, R., P. E. Walton, and T. D. Etherton. 1989. An acid-stable insulin-like growth factor (IGF)-binding protein from pig serum inhibits binding of IGF-I and IGF-II to vascular endothelial cells. J. Endocrinol. 120:231-236.

22. DeMellow, J. S. M., and R. C. Baxter. 1988. Growth hormone-dependent insulin-like growth factor (IGF) binding protein both inhibits and potentiates IGF-I-stimulated DNA synthesis in human skin fibroblasts. Biochem. Biophys. Res. Commun. 156:199-204.

23. Busby, W. H., Jr., D. G. Klapper, and D. R. Clemmons. 1988. Purification of a 31,000-dalton insulin-like growth factor binding protein from human amniotic fluid. Isolation of two forms with different biologic actions. J. Biol. Chem. 263:14203-14210.

24. Conover, C. A., F. Liu, D. Powell, R. G. Rosenfeld, and R. L. Hintz. 1989. Insulin-like growth factor binding proteins from cultured human fibroblasts: characterization and hormonal regulation. J. Clin. Invest. 83:852-859.

25. Martin, J. L., and R. C. Baxter. 1988. Insulin-like growth factor-binding proteins (IGF-BPs) produced by human skin fibroblasts: immunological relationship to other human IGF-BPs. Endocrinology. 123:1907-1915.

26. Rosenfeld, R. G., and L. A. Dollar. 1982. Characterization of the somatomedin-C/insulin-like growth factor I (SM-C/IGF-I) receptor on cultured human fibroblast monolayers: regulation of receptor concentrations by SM-C/IGF-I and insulin. J. Clin. Endocrinol. Metab. 55:434-439.

27. Hossenlopp, P., D. Seurin, B. Segovia-Quinson, S. Hardouin, and M. Binoux. 1986. Analysis of serum insulin-like growth factor binding proteins using Western blotting: use of the method for titration of the binding proteins and competitive binding studies. Anal. Biochem. 154:138-143.

28. Hancock, K., and V. C. W. Tsang. 1983. India Ink staining of proteins on nitrocellulose paper. Anal. Biochem. 133:157-162.

29. Conover, C. A., R. G. Rosenfeld, and R. L. Hintz. 1987. Insulin-like growth factor II binding and action in human fetal fibroblasts. J. Cell. Physiol. 133:560-566.

30. Conover, C. A., P. Misra, R. L. Hintz, and R. G. Rosenfeld. 1988. Differential binding of [ ${ }^{125}$ I]IGF-I to human fibroblast monolayers. Acta Endocrinol. 118:513-520.

31. McCusker R. H., C. Camacho-Hubner, M. L. Bayne, M. A. Cascieri, and D. R. Clemmons. 1990. Insulin-like growth factor (IGF) binding to human fibroblast and glioblastoma cells: the modulating effect of cell released IGF binding proteins (IGFBPs). J. Cell. Physiol. 144:244-253.

32. Conover, C. A., P. Misra, R. L. Hintz, and R. G. Rosenfeld. 1986. Effect of anti-insulin-like growth factor I receptor antibody on insulin-like growth factor II stimulation of DNA synthesis in human fibroblasts. Biochem. Biophys. Res. Commun. 139:501-508.

33. Banskota, N. K., J.-L. Carpenter, and G. L. King. 1986. Processing and release of insulin and insulin-like growth factor I by macro- and microvascular endothelial cells. Endocrinology. 119:1904-1913.

34. Martin, J. L., and R. C. Baxter. 1986. Insulin-like growth factor-binding protein from human plasma. J. Biol. Chem. 261:8754-8760.

35. Cascieri, M. A., G. G. Chicchi, J. Applebaum, N. S. Hayes, B. G. Green, and M. L. Bayne. 1988. Mutants of human insulin-like growth factor I with reduced affinity for the type I insulin-like growth factor receptor. Biochemistry. 27:3229-3233.

36. Bayne, M. L., J. Applebaum, D. Underwood, G. G. Chicchi, B. G. Green, N. S. Hayes, and M. A. Cascieri. 1988. The C region of human insulin-like growth factor (IGF) I is required for high affinity binding to the type 1 IGF receptor. $J$. Biol. Chem. 264:11004-11008.

37. Bayne, M. L., J. Applebaum, G. G. Chicchi, N. S. Hayes, B. G. Green, and M. A. Cascieri. 1988. Structural analogs of human insulin-like growth factor I 
with reduced affinity for serum binding proteins and the type 2 insulin-like growth factor receptor. J. Biol. Chem. 263:6233-6239.

38. Massague, J., and M. P. Czech. 1982. The subunit structure of two distinct receptors for insulin-like growth factors I and II and their relationship to the insulin receptor. J. Biol. Chem. 257:5038-5045.

39. Hardouin, S., P. Hossenlopp, B. Segovia, D. Seurin, G. Portolan, C. Lassare, and M. Binoux. 1987. Heterogeneity of insulin-like growth factor binding proteins and relationships between structure and affinity. 1. Circulating forms in man. Eur. J. Biochem. 170:121-132.

40. Zapf, J., M. Kiefer, J. Merryweather, F. Masiarz, D. Bauer, W. Born, J. A. Fischer, and E. R. Froesch. 1990. Isolation from adult human serum of four insulin-like growth factor (IGF) binding proteins and molecular cloning of one of them that is increased by IGF I administration and in extrapancreatic tumor hypoglycemia. J. Biol. Chem. 265:14892-14898.

41. Donahue, L. R., S. J. Hunter, A. P. Sherblom, and C. Rosen. 1990. Age-related changes in serum insulin-like growth factor-binding proteins in women. $J$. Clin. Endocrinol. Metab. 71:575-579.

42. Hill, D. J., C. Camacho-Hubner, P. Rashid, A. J. Strain, and D. R. Clemmons. 1988. Insulin-like growth factor (IGF)-binding protein release by human fetal fibroblasts: dependency on cell density and IGF peptides. J. Endocrinol. 122:87-98.

43. Mohan, S., C. M. Bautista, J. Wergedal, and D. J. Baylink. 1989. Isolation of an inhibitory insulin-like growth factor (IGF) binding protein from bone cellconditioned medium: a potential local regulator of IGF action. Proc. Natl. Acad. Sci. USA. 86:8338-8342.

44. Clemmons, D. R., M. A. Cascieri, C. Camacho-Hubner, R. H. McCusker, and M. L. Bayne. 1990. Discrete alterations of the insulin-like growth factor I molecule which alter its affinity for insulin-like growth factor-binding proteins result in changes in bioactivity. J. Biol. Chem. 265:12210-12216.

45. Conover, C. A., and P. D. K. Lee. 1990. Insulin regulation of insulin-like growth factor-binding protein production in cultured $\mathrm{HepG}_{2}$ cells. J. Clin. Endocrinol. Metab. 70:1062-1067.

46. Seneviratne, C., L. Jiangming, and L. J. Murphy. 1990. Transcriptional regulation of rat insulin-like growth factor-binding protein-1 expression by growth hormone. Mol. Endocrinol. 4:1199-1204.

47. Boni-Schnetzler, M., C. Schmid, J.-L. Mary, B. Zimmerli, P. J. Meier, J. Zapf, J. Schwander, and E. R. Froesch. 1990. Insulin regulates the expression of the insulin-like growth factor binding protein $2 \mathrm{mRNA}$ in rat hepatocytes. $\mathrm{Mol}$. Endocrinol. 4:1320-1326.

48. Schwander, J., C. Schmid, J. L. Mary, I. Schlapfer, M. Boeni-Schnetzler, and E. R. Froesch. 1991. IGFBP-3 in tissues and primary cell cultures of the rat. 2nd International IGF Symposium. $235 a$. (Abstr.).

49. Crettaz, M., and C. R. Kahn. 1984. Insulin receptor regulation and desensitization in rat hepatoma cells. Concomitant changes in receptor number and in binding affinity. Diabetes. 33:477-485.

50. Yeoh, S. I., and R. C. Baxter. 1988. Metabolic regulation of the growth hormone independent insulin-like growth factor binding protein in human plasma. Acta Endocrinol. 119:465-473.

51. Conover, C. A., and D. R. Powell. 1991. Insulin-like growth factor (IGF) binding protein-3 blocks IGF-I-induced receptor down-regulation and cell desensitization in cultured bovine fibroblasts. Endocrinology. 129:710-716.

52. Ernst, M., and G. A. Rodan. 1990. Increased activity of insulin-like growth factor (IGF) in osteoblastic cells in the presence of growth hormone (GH): positive correlation with the presence of the GH-induced IGF-binding protein BP-3. Endocrinology. 127:807-814.

53. Blum, W. F., E. W. Jenne, F. Reppin, K. Kietzmann, M. B. Ranke, and J. R. Bierich. 1989. Insulin-like growth factor I (IGF-I)-binding protein complex is a better mitogen than free IGF-I. Endocrinology. 125:766-772.

54. Baxter, R. C. 1988. Characterization of the acid-labile subunit of the growth hormone-dependent insulin-like growth factor binding protein complex. J. Clin. Endocrinol. Metab. 67:265-272. 